\title{
Variability in modern sea surface temperature, sea ice and terrigenous input in the sub-polar North Pacific and Bering Sea: Reconstruction from biomarker data
}

\author{
Marie Méheust*, Kirsten Fahl, Ruediger Stein \\ Alfred Wegener Institute for Polar and Marine Research, Department of Marine Geology and Paleontology, Columbusstrasse, D-27568 Bremerhaven, Germany
}

\section{A R T I C L E I N F O}

\section{Article history:}

Received 5 September 2012

Received in revised form 16 January 2013

Accepted 18 January 2013

Available online 29 January 2013

\begin{abstract}
A B S T R A C T
In order to study the modern sea surface characteristics of the sub-polar North Pacific and the Bering Sea, i.e. sea surface temperature (SST) and sea ice cover, surface sediments recovered during the RV Sonne Expedition 202 in 2009 were analysed. To distinguish between marine and terrestrial organic carbon, hydrogen index values, long chain $n$-alkanes and specific sterols have been determined. The results show that in the Bering Sea, especially on the sea slope, the organic carbon source is mainly caused by high primary production. In the North Pacific, on the other hand, the organic material originates predominantly from terrestrial higher plants, probably related to dust input from Asia. SST has been reconstructed using the modified alkenone unsaturation index. Calibration from Müller et al. (1998) offers the most reliable estimate of mean annual temperature in the central North Pacific but does not correlate with mean annual temperature throughout the study area. In the eastern North Pacific and the Bering Sea, the Sikes et al. (1997) calibration seems to be more accurate and matches summer SST. The distribution of the novel sea ice proxy $\mathrm{IP}_{25}$ (highly branched $\mathrm{C}_{25}$ isoprenoid alkene) in surface sediments is in accord with the modern spring sea ice edge and shows the potential of this proxy to track past variation in sea ice cover in the study area.
\end{abstract}

(c) 2013 Elsevier Ltd. All rights reserved.

\section{Introduction}

The Bering Sea, a semi-enclosed sea between the Arctic and North Pacific oceans, is one of the most productive ecosystems, representing $1.5 \%$ of the total primary productivity in the oceans (Tsyban, 1999). Recent climate change has had a strong impact on the ecosystem of the area and, since the mid-1970s, important changes in the abundance of phytoplankton, zooplankton and fish have been observed (Hunt et al., 2002). Furthermore, the most drastic future temperature changes are expected at high latitude. Over the last few decades, sea surface temperature (SST) increased by about $3{ }^{\circ} \mathrm{C}$ in the Bering Sea (Stabeno et al., 2007, 2010). Sea ice, with its strong seasonal variability, is a critical component of the Bering Sea system and is extremely sensitive to changes in weather and climate (Overland, 1981). In November, the ice spreads through the Bering Strait and reaches its maximum extent in early spring (March-April), to as far south as $54.5^{\circ} \mathrm{N}$ in years characterised by high ice extent (Stabeno et al., 2007). Between July and September, the Bering Sea is ice-free (Niebauer, 1980, 1983). Over the last 30 years, the sea ice cover has been decreasing in terms of concentration and duration, and a significant extension of the ice-free

\footnotetext{
* Corresponding author. Tel.: +49 4714831 1448; fax: +49 47148311149 .

E-mail address: marie.meheust@awi.de (M. Méheust).
}

season has been observed (Stabeno et al., 2007; Danielson et al., 2011).

The surface water circulation in the western North Pacific is dominated by the Kuroshio Current (KC), which flows along the Japanese coast. Entering the central North Pacific the KC is renamed the Kuroshio Extension (KuE). Flowing eastward, this current becomes wider and forms the North Pacific Current (NPC) around $171^{\circ} \mathrm{E}$ (Fig. 1; Qiu, 2000). Two currents originating from the NPC dominate the circulation in the Gulf of Alaska (Stabeno et al., 2004) - the Alaskan Current (AC) and the Alaskan Coastal Current (ACC). These two currents, flowing through the Aleutian passes, form the cyclonic circulation found in the Bering Sea. In the eastern Bering Sea basin, the two principal currents are the Aleutian North Slope Current (ANSC; Stabeno and Reed, 1994), which flows eastward along the north side of the Aleutian Islands, and the Bering Slope Current (BSC; Schumacher and Reed, 1992), which is an extension of the Aleutian North Slope Current (ANSC) and flows northward along the continental slope (Fig. 1). Two currents leave the Bering Sea through the Bering Strait, the West Alaska Current (WAC) originating from the ACC, and the Anadyr Current, a northern branch originating from the BSC. The Kamchatka Current $(\mathrm{KC})$ is the second branch originating from the division of the BSC, flowing southward along the Siberia-Kamchatka Peninsula coast and then forming the Oyashio Current (Fig. 1). 


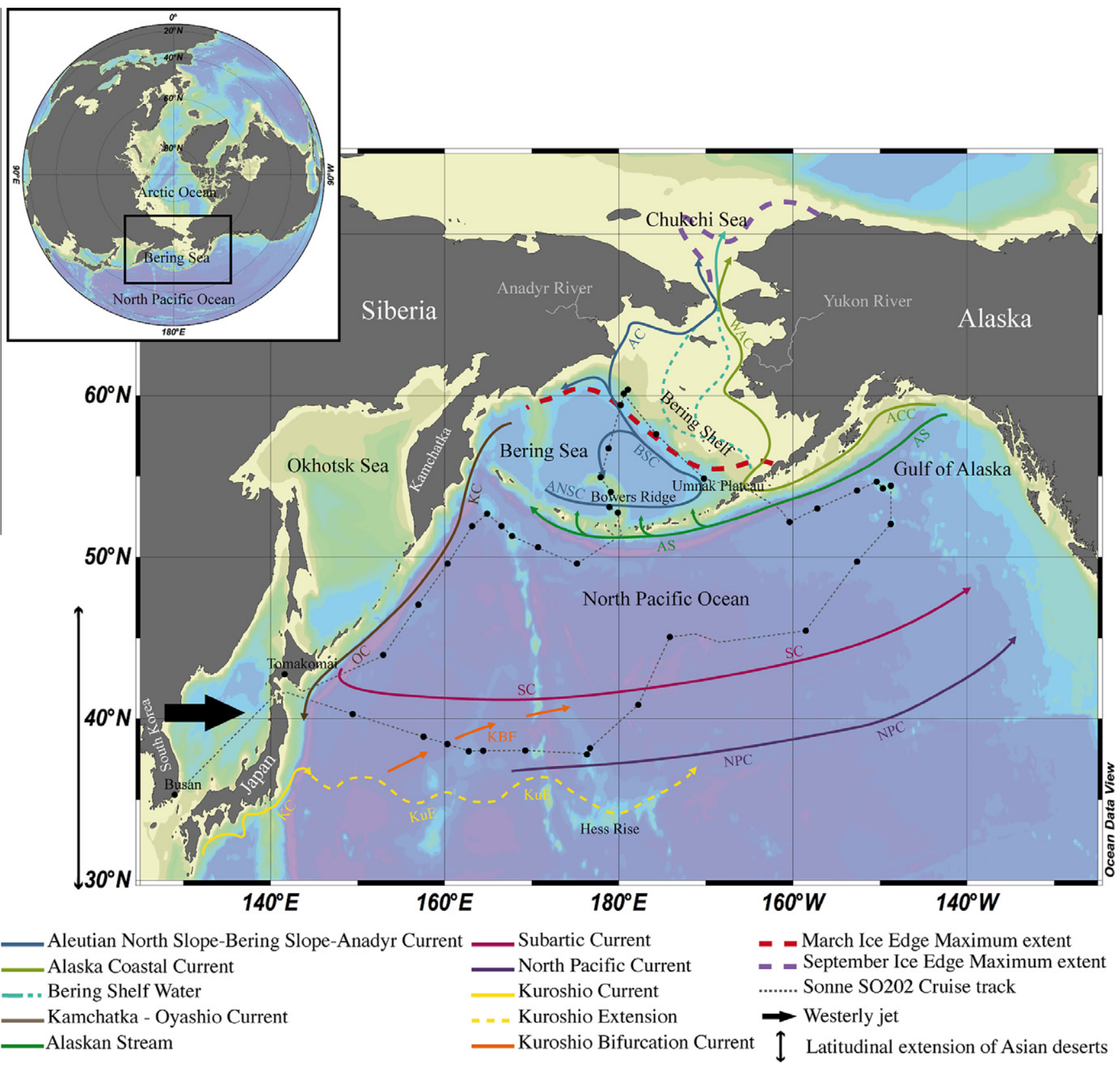

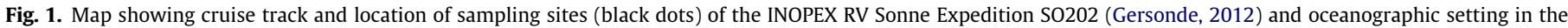

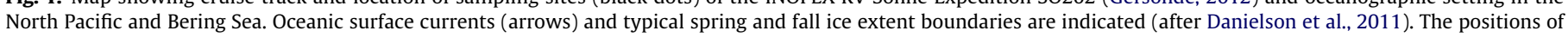
the main path of the westerly jet stream and the latitudinal extension of the Asian deserts are also highlighted (after Bao et al., 2012).

In this study, we report results of the analysis of surface sediment samples $(0-1 \mathrm{~cm})$ from the sub-polar North Pacific and Bering Sea. The main objectives were to (i) determine the organic carbon distribution and distinguish between terrigenous and marine sources, (ii) reconstruct the SST and (iii) reconstruct modern sea ice distribution from proxy data. Furthermore, the data should be useful for a better interpretation of data from sediment cores representing past climate change in the area.

\section{Biomarkers as proxies for environmental reconstruction}

In order to interpret organic matter (OM) input in terms of environmental conditions, information on its quantity and quality is needed. In this context, the distinction between marine and terrigenous OM sources is of overall interest. This goal can be reached by studying different organic geochemical proxies, such as total organic carbon (TOC) content, hydrogen index (HI) values and $\mathrm{C} / \mathrm{N}$ ratio (e.g. Tissot and Welte, 1984; Birgel et al., 2004; Stein and Macdonald, 2004; Stein, 2008 and references therein). More precise information about OM sources can be obtained by using specific biomarkers. To identify marine sources, dinosterol $(4 \alpha-$ 23,24-trimethyl-5 $\alpha$-cholest-22E-en-3 $\beta$-ol), synthesised by dinoflagellates (Boon et al., 1979) and a diatom (Volkman, 2006), and brassicasterol (and/or epi-brassicasterol depending on the stereochemistry at C-24; 24 -methylcholesta-5,22-E-dien-3 $\beta$-ol) synthesised by diatoms and haptophytes (Volkman, 2006), are often applied as proxies. On the other hand, $\beta$-sitosterol (24-ethylcho-

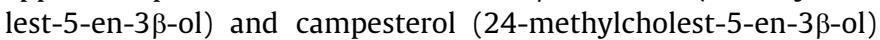
are typical sterols of terrestrial higher plant origin (Huang and Meinschein, 1976; Volkman, 1986). Together with odd numbered 
long chain $n$-alkanes, derived from higher plant leaf wax (Eglinton and Hamilton, 1963, 1967), we used these biomarkers to reconstruct the terrestrial input.

SST can be estimated from specific long chain alkenones synthesised mainly by haptophyte algae, i.e. coccolithophores such as Emiliania huxleyi and Gephyrocapsa oceanica (Volkman et al., 1980; Marlowe et al., 1984). In this approach, the modified alkenone unsaturation index $U_{37}^{K^{\prime}}$ is used (Brassell et al., 1986). $U_{37}^{K^{\prime}}$ (Prahl and Wakeham, 1987) corresponds to the relative abundance of methyl alkenones with 37 carbons and two or three double bonds. Its calibration vs. SST was initially derived from phytoplankton cultures (Prahl et al., 1988). The most commonly used calibration (Müller et al., 1998) is derived from $U_{37}^{K^{\prime}}$ data determined from core top sediments from the global ocean between $60^{\circ} \mathrm{S}$ and $60^{\circ} \mathrm{N}$.

Reconstruction of sea ice conditions is often based on sea iceassociated organisms such as diatoms (e.g. Katsuki and Takahashi, 2005) and dinocysts (e.g. Bonnet et al., 2012). Very recently, a novel biomarker proxy, $\mathrm{IP}_{25}$, was developed for reconstruction of sea ice cover (Belt et al., 2007). It is based on a monounsaturated highly branched isoprenoid (HBI) lipid produced by sea ice diatoms during the spring bloom period and present in the underlying sediment after ice melting (Belt et al., 2010). When using $\mathrm{IP}_{25}$ as sea ice proxy one has to consider that its absence may refer to either a lack of sea ice or, in contrast, a permanent and thick ice cover limiting any algal growth. In this context, the combination of $\mathrm{IP}_{25}$ with a phytoplankton marker proves valuable for properly interpreting the sea ice proxy signal (Müller et al., 2009, 2011, 2012). Meanwhile, the approach has been used successfully for reconstructing paleo-sea ice distributions from marine sediment cores recovered from the Fram Strait/Yermak Plateau (Müller et al., 2009, 2011, 2012; Stein and Fahl, 2012), North Iceland Shelf (Massé et al., 2008; Andrews et al., 2009), Canadian Arctic Archipelago (Vare et al., 2009; Belt et al., 2010; Brown et al., 2011) and Lomonosov Ridge/central Arctic Ocean areas (Fahl and Stein, 2012; Stein et al., 2012).

\section{Material and methods}

Surface sediment samples were collected during the INOPEX RV Sonne Expedition 202 in 2009 using a multicorer (Gersonde, 2012; Fig. 1). The short cores were sampled in $1 \mathrm{~cm}$ sections, and the upper part $(0-1 \mathrm{~cm})$ was used for bulk parameter and biomarker analyses. All samples were stored at $-30{ }^{\circ} \mathrm{C}$ in glass bottles until further processing. For bulk analysis the sediment was freeze dried and homogenised. The TOC content was measured by means of a LECO CS-125 elemental analyser. The hydrogen index (HI in $\mathrm{mg} \mathrm{HC} / \mathrm{g} \mathrm{TOC}$ ) was determined via Rock-Eval pyrolysis, as described by Espitalié et al.

Table 1

Information and data on samples (n.d., not determined).

\begin{tabular}{|c|c|c|c|c|c|c|c|c|c|c|}
\hline Station & Latitude & Longitude & $\mathrm{WD}(\mathrm{m})$ & TOC (wt.\%) & $\begin{array}{l}\mathrm{HI} \\
(\mathrm{mg} \mathrm{HC} / \mathrm{g} \mathrm{OC})\end{array}$ & $\mathrm{C} / \mathrm{N}$ & $\begin{array}{l}\text { Brassicasterol } \\
(\mu \mathrm{g} / \mathrm{g} \text { OC })\end{array}$ & $\begin{array}{l}\text { Dinosterol } \\
(\mu \mathrm{g} / \mathrm{g} \mathrm{OC})\end{array}$ & $\begin{array}{l}\Sigma \text { Campesterol, } \\
\beta \text {-sitosterol } \\
(\mu \mathrm{g} / \mathrm{g} \mathrm{OC})\end{array}$ & $\begin{array}{l}\Sigma n-C_{27}, n-C_{29} \\
n-C_{31}(\mu \mathrm{g} / \mathrm{g} \text { OC })\end{array}$ \\
\hline \multicolumn{11}{|c|}{ Western North Pacific } \\
\hline SO202-01-3 & 44.03 & 152.92 & 5282 & 0.78 & 143 & 5.7 & 50 & 7.7 & 161 & 106 \\
\hline SO202-02-4 & 46.97 & 156.98 & 4822 & 0.35 & 147 & 4.6 & 54 & 20 & 190 & 142 \\
\hline SO202-03-4 & 49.61 & 160.38 & 5429 & 0.63 & 112 & 5.4 & 71 & 24 & 372 & 91 \\
\hline SO202-04-3 & 51.86 & 163.16 & 5273 & 0.45 & 142 & 5.1 & 55 & 21 & 250 & 119 \\
\hline SO202-05-3 & 52.70 & 164.92 & 3362 & 0.49 & 120 & 8.6 & 75 & 13 & 250 & 120 \\
\hline SO202-06-2 & 51.90 & 166.49 & 3422 & 0.26 & 91 & 27.1 & 26 & 8.1 & 108 & 126 \\
\hline SO202-07-2 & 51.27 & 167.70 & 2349 & 0.37 & 120 & 30.6 & 110 & 27 & 365 & 75 \\
\hline SO202-08-1 & 50.54 & 170.82 & 3630 & 0.42 & 120 & 5.1 & 58 & 18 & 180 & 91 \\
\hline SO202-09-2 & 49.66 & 175.16 & 5028 & 0.52 & 118 & 5.8 & 21 & 5.3 & 64 & 86 \\
\hline \multicolumn{11}{|l|}{ Bering Sea } \\
\hline SO202-10-2 & 52.74 & 179.85 & 1488 & 1.18 & 296 & 8.8 & 100 & 63 & 262 & 44 \\
\hline SO202-11-1 & 53.11 & 178.90 & 2704 & 0.45 & 141 & 6.0 & 121 & 25 & 336 & 65 \\
\hline SO202-12-2 & 54.05 & 179.09 & 2108 & 0.71 & 203 & 7.3 & 106 & 1.7 & 247 & 68 \\
\hline SO202-13-4 & 54.98 & 177.96 & 1383 & 0.37 & 114 & 20.0 & n.d & n.d. & n.d. & 51 \\
\hline SO202-14-5 & 56.79 & 178.82 & 3822 & 0.63 & 149 & 5.8 & n.d & n.d & n.d. & 106 \\
\hline SO202-15-4 & 59.51 & -179.85 & 3137 & 1.16 & 212 & 6.6 & 51 & 42 & 224 & 129 \\
\hline SO202-16-1 & 60.40 & -179.11 & 548 & 0.40 & 45 & 5.4 & 12 & 4.6 & 38 & 62 \\
\hline SO202-18-1 & 60.13 & -179.44 & 1108 & 0.62 & 234 & 7.4 & 281 & 109 & 992 & 139 \\
\hline SO202-21-2 & 54.79 & -170.33 & 1911 & 1.51 & 259 & 6.5 & 229 & 87 & 360 & 32 \\
\hline SO202-22-1 & 54.57 & -168.81 & 1478 & 1.39 & 253 & 6.3 & 100 & 47 & 140 & 37 \\
\hline \multicolumn{11}{|c|}{ Eastern North Pacific } \\
\hline SO202-23-4 & 52.17 & -160.50 & 4613 & 0.53 & 129 & 3.7 & 129 & 26 & 241 & 46 \\
\hline SO202-24-2 & 53.00 & -157.19 & 4565 & 0.45 & 124 & 2.9 & 86 & 9.7 & 123 & 40 \\
\hline SO202-25-1 & 54.10 & -152.69 & 4588 & 0.47 & 104 & 2.4 & 26 & 9.7 & 853 & 64 \\
\hline SO202-26-1 & 54.64 & -150.38 & 742 & 0.30 & 140 & 33.6 & 131 & 21 & 140 & 37 \\
\hline SO202-27-1 & 54.30 & -149.60 & 2916 & 0.32 & 100 & 30.7 & 65 & 17 & 205 & 78 \\
\hline SO202-28-1 & 54.42 & -148.88 & 3710 & 0.52 & 100 & 10.5 & 25 & 7.6 & 90 & 61 \\
\hline SO202-29-5 & 52.03 & -148.89 & 3984 & 0.35 & 89 & 19.8 & 24 & 8.1 & 116 & 90 \\
\hline SO202-31-5 & 49.68 & -152.55 & 3744 & 0.18 & 101 & 101.1 & 62 & 5.7 & 180 & 101 \\
\hline SO202-32-5 & 45.50 & -158.50 & 5302 & 0.43 & 109 & 5.6 & 20 & 5.3 & 72 & 137 \\
\hline SO202-33-5 & 45.08 & -174.14 & 6159 & 0.43 & 129 & 5.2 & 31 & 6.7 & 98 & 216 \\
\hline \multicolumn{11}{|c|}{ Central North Pacific } \\
\hline SO202-34-2 & 40.89 & -177.68 & 5713 & 0.46 & 150 & 5.0 & 69 & 12 & 227 & 355 \\
\hline SO202-36-6 & 38.19 & 176.70 & 4522 & 0.51 & 103 & 5.8 & 69 & 12 & 230 & 120 \\
\hline SO202-38-1 & 38.04 & 169.28 & 5503 & 0.50 & 115 & 5.8 & 6.7 & 3.4 & 26 & 172 \\
\hline SO202-39-2 & 38.01 & 164.45 & 5096 & 0.64 & 124 & 6.7 & 31 & 22 & 154 & 130 \\
\hline SO202-40-2 & 38.00 & 162.68 & 3462 & 0.34 & 95 & 124.8 & 30 & 11 & 140 & 83 \\
\hline SO202-41-3 & 38.41 & 160.33 & 5408 & 0.71 & 122 & 6.7 & n.d & n.d. & n.d. & 158 \\
\hline SO202-42-3 & 38.89 & 157.63 & 5535 & 0.68 & 120 & 7.1 & 12 & 17 & 57 & 106 \\
\hline SO202-45-2 & 40.29 & 149.49 & 5476 & 0.93 & 132 & 7.3 & n.d. & n.d. & n.d. & 105 \\
\hline
\end{tabular}


(1977). When using Rock-Eval data derived from TOC-poor $(<0.5 \%)$ sediment samples, HI values should be interpreted with caution. For lipid analysis, 1-5 g of freeze dried and homogenised sediment were extracted using accelerator solvent extraction (DIONEX-ASE 200; $\left.100{ }^{\circ} \mathrm{C}, 5 \mathrm{~min}, 1000 \mathrm{psi}\right)$ using $\mathrm{CH}_{2} \mathrm{Cl}_{2} / \mathrm{MeOH}(2: 1, \mathrm{v} / \mathrm{v})$. For quantification, the following internal standards were added before any analytical step: squalane $(0.48 \mu \mathrm{g} / \mathrm{sample})$, 7-hexylnonadecane $(0.0766 \mu \mathrm{g} / \mathrm{sample})$, and cholesterol- $\mathrm{d}_{6}\left({ }^{2} \mathrm{H}_{6}\right.$ cholesterol-5-en-3 $\beta-$ $\mathrm{ol} ; 2.2 \mu \mathrm{g} /$ sample). An aliquot of the total extract was used for analysing $n$-alkanes, $\mathrm{IP}_{25}$, alkenones and sterols.

The $n$-alkanes and $\mathrm{IP}_{25}$ were separated from the other fractions via column chromatography $\left(\mathrm{SiO}_{2}\right)$ using $n$-hexane $(5 \mathrm{ml})$ as eluent. Due to coelution with unknown compounds, an additional fractionation step using $\mathrm{CH}_{2} \mathrm{Cl}_{2} /$ hexane $(1: 1 \mathrm{v} / \mathrm{v}, 5 \mathrm{ml})$ was required. The alkenones were separated from the other fractions using $\mathrm{CH}_{2} \mathrm{Cl}_{2}(5 \mathrm{ml})$ as eluent. After extraction with EtOAc/hexane $(5 \mathrm{ml}, 20: 80 \mathrm{v} / \mathrm{v})$, the sterols were silylated with $500 \mu \mathrm{l}$ BSTFA (bistrimethylsilyltrifluoroacetamide; $60^{\circ} \mathrm{C}, 2 \mathrm{~h}$ ).

$\mathrm{IP}_{25}$ and sterols were analysed using gas chromatography-mass spectrometry (GC-MS; Agilent 6850; $30 \mathrm{~m} \mathrm{HP-5} \mathrm{ms} \mathrm{column,}$ $0.25 \mathrm{~mm}$ i.d., $0.25 \mu \mathrm{m}$ film thickness; coupled to an Agilent 5975C VL mass selective detector). For further details see Müller et al. (2011) and Fahl and Stein (2012). The $n$-alkanes and alkenones were analysed using GC (HP6890) as described by Fahl and Stein (1997). Assignment was achieved from GC retention time and quantification by means of the internal standards. In order to com-
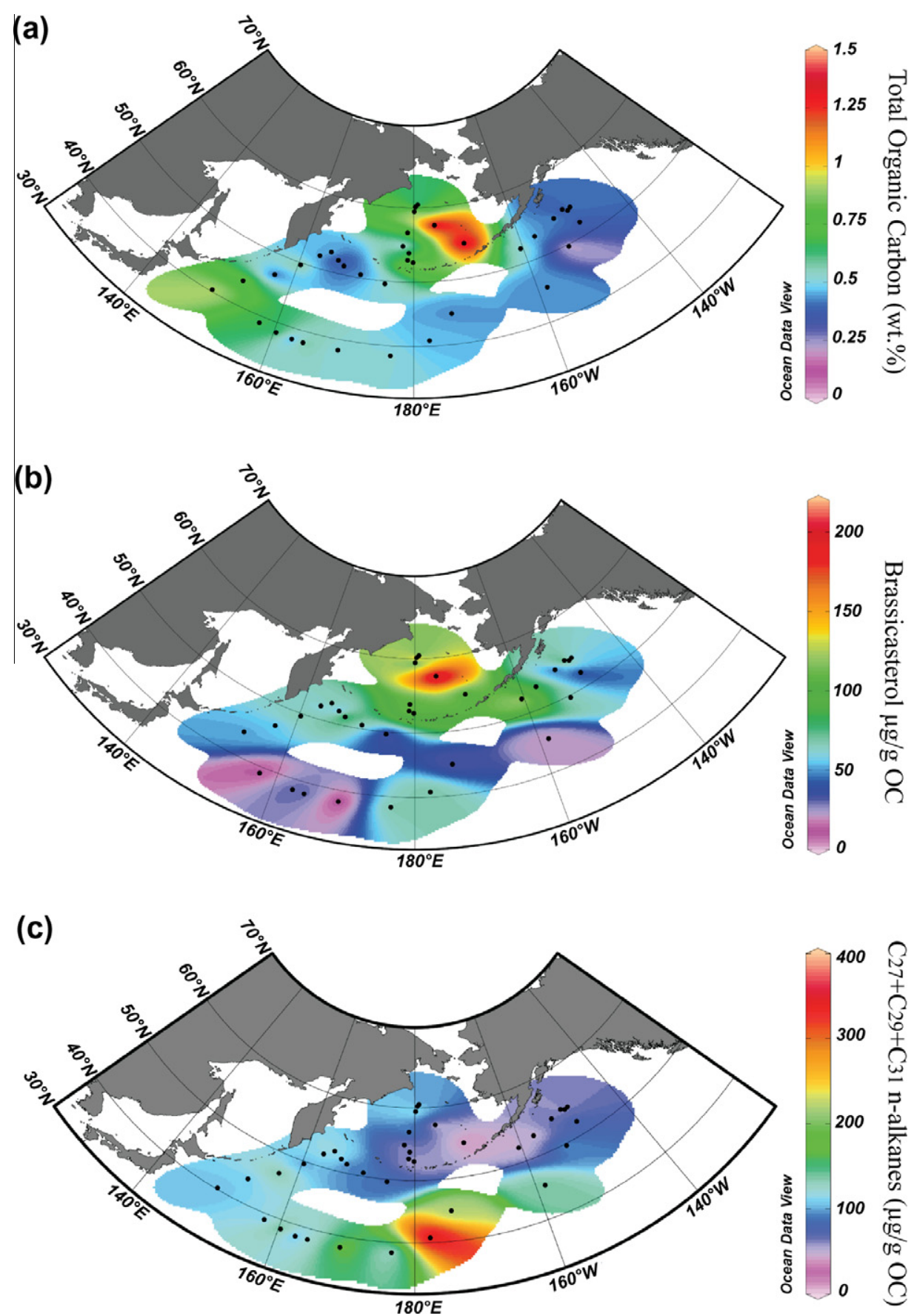

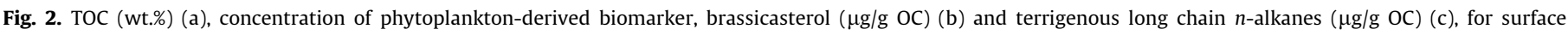
sediments from the North Pacific and Bering Sea. Black dots indicate sites of sediment samples. 

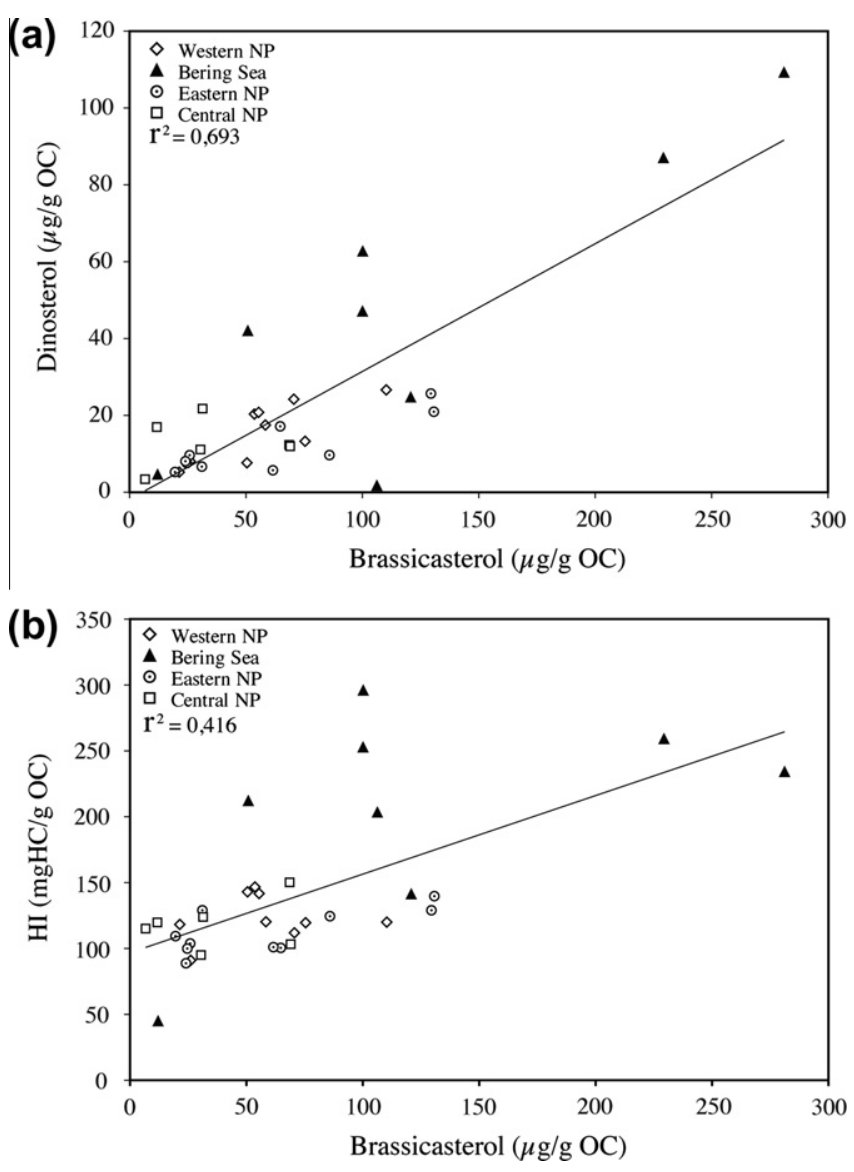

Fig. 3. (a) Correlation between concentration of phytoplankton-derived brassicasterol vs. dinosterol ( $\mu \mathrm{g} / \mathrm{g} \mathrm{OC}$ ) and (b) $\mathrm{HI}(\mathrm{mg} / \mathrm{g} \mathrm{OC})$ vs. brassicasterol $(\mu \mathrm{g} / \mathrm{g} \mathrm{OC})$ in surface sediments from the North Pacific and Bering Sea.

pensate for variation in sedimentation rate, absolute biomarker concentrations were normalised to TOC.

\section{Results and discussion}

\subsection{OM sources}

TOC content, HI values and biomarker concentrations were used to distinguish between marine and terrigenous sources of $\mathrm{OM}$ and to interpret the data in relation to primary productivity and terrigenous input, respectively (Fahl and Stein, 1997, 1999; Schubert and Stein, 1997; Sicre et al., 2000; Amo and Minagawa, 2003; Birgel et al., 2004; Yunker et al., 2005; Walinsky et al., 2009).

The TOC content of surface sediment samples varies between 0.18 and 1.51 wt.\% (Table 1, Fig. 2a). The highest values are restricted to the westernmost part of the North Pacific and to the continental slope of the Bering Sea. In order to obtain preliminary information about the origin of the OM, i.e. the terrigenous vs. marine proportion, HI was determined. The values, ranging between 92 and $235 \mathrm{mg} \mathrm{HC} / \mathrm{g} \mathrm{C}$ (Table 1), point to different OC sources. At the Bering Sea slope, high TOC values correlate with high HI values (> $200 \mathrm{mg} \mathrm{HC} / \mathrm{g} \mathrm{C}$ ), suggesting a marine source of the OM. The marine origin is supported by biomarker data. The concentration of brassicasterol and dinosterol, both indicative for marine phytoplankton (Boon et al., 1979; Nichols et al., 1984; Volkman, 2006), varies between $6.7-281 \mu \mathrm{g} / \mathrm{g}$ TOC and $1.7-109 \mu \mathrm{g} / \mathrm{g}$ TOC, respectively, with the maximum concentration occurring along the Bering Sea slope (Table 1, Fig. 2c). The good to fair correlation (Fig. 3a) between brassicasterol and dinosterol $\left(r^{2} 0.69\right)$ and between brassicasterol and HI values ( $r^{2} 0.42$; Fig. $\left.3 \mathrm{~b}\right)$, underline the dominance of marine-derived OM in the area.

The data are in agreement with the Bering Sea "Green Belt", a region of enhanced nutrient supply to the shelf edge euphotic zone introduced via physical processes, such as intensive tidal mixing, transverse circulation and eddies in the Bering Slope Current (Springer et al., 1996). Due to these processes, it is the most productive area in the Bering Sea. This high productivity realm is also reflected in elevated sea surface chlorophyll $a$ concentration, determined from satellite ocean colour observations (e.g. Mizobata et al., 2002; Mizobata and Saitoh, 2004; Okkonen et al., 2004; Iida and Saitoh, 2007). Based on chlorophyll $a$ data, the Bering Sea can be divided into two regions: The shelf region (including shelf break) is characterised by a large phytoplankton bloom in May and high chlorophyll $a$ concentration $\left(>2 \mathrm{mg} / \mathrm{m}^{-3}\right.$ ) during summer, while the basin area is characterised by a low concentration $\left(<1 \mathrm{mg} / \mathrm{m}^{-3}\right)$ throughout the year (Iida and Saitoh, 2007). Furthermore, the enrichment in marine OM may also be related to increased primary productivity along the ice edge, as described for the Laptev Sea (Fahl and Stein, 1997; Boetius and Damm, 1998). In the Bering Sea, a similar intense and short lived phytoplankton bloom occurs at the marginal ice zone in spring when the sea ice retreats (Niebauer et al., 1990, 1995), leading to an enrichment in marine OM.

For the central North Pacific, low HI values (< $150 \mathrm{mg} \mathrm{HC} / \mathrm{g} \mathrm{C}$; Table 1) point to a predominance of terrigenous OM input. This interpretation is supported by the distribution of odd long chain $n$-alkanes $\left(C_{27}, C_{29}\right.$ and $\left.C_{31}\right)$, a reliable proxy for the input from higher plants (e.g. Yunker et al., 1995; Fahl and Stein, 1997). The concentration of these long chain $n$-alkanes varies between 32.4 and $355 \mu \mathrm{g} / \mathrm{g}$ TOC with higher values occurring in the eastern and central North Pacific (Table 1; Fig. 2c). In addition, specific sterols, i.e. campesterol and $\beta$-sitosterol, both often used as proxies for terrestrial OM (Huang and Meinschein, 1976; Volkman, 1986), were also measured. The summed concentration of the two varies generally between 40 and $400 \mu \mathrm{g} / \mathrm{g}$ TOC, with higher values in the Bering Sea and eastern North Pacific (Table 1). In our samples, however, these sterols do not show any (negative or positive) correlation with $\mathrm{HI}\left(r^{2} 0.11\right)$ and the long chain $n$-alkanes $\left(r^{2} 0.003\right)$, respectively. Thus, here the sterols seem to provide ambiguous evidence for terrigenous OM as they may also be synthesised by phytoplankton (Volkman, 1986).

Two different transport processes may be responsible for the presence of terrestrial OM in the open ocean, away from coastal zones more influenced by direct riverine input (cf., Stein and Macdonald, 2004): (i) wind transport and (ii) ocean current transport. The wind transported mineral fraction is certainly an important source of sediments in the central North Pacific. Kawahata et al. (2000) analysed sediments from a site close to our study area, i.e. core H3571 from the Hess Rise $\left(34^{\circ} 54.25^{\prime} \mathrm{N}\right.$ and $\left.179^{\circ} 42.18^{\prime} \mathrm{E}\right)$, and identified aeolian quartz grains. The sources of mineral dust on the Asian continent are widespread and include the Gobi and the Takla Makan deserts and the immense loess deposits in China (Prospero et al., 1989). Our sampling site in the North Pacific, characterised by low HI values, is located below the Northern Hemisphere westerly winds, the main pathway for dust input from Asia (Fig. 1). This atmospheric transport is responsible for $>6-$ $12 \times 10^{6}$ tonnes of annual dust deposition over the North Pacific (Uematsu et al., 1983) and is probably the source of the high terrestrial OM content of the surface sediments. In addition, ocean currents may also play an important role in the transportation of the OM. Kawahata and Ohshima (2002) showed that pollen and spores, both terrigenous sources of OM found in core H3571 on Hess Rise, originated from the Asian continent and from Japan, and were transported by the Kuroshio Current and Kuroshio Extension between $42^{\circ}$ and $30^{\circ} \mathrm{N}$. 
Table 2

Location of samples and data.

\begin{tabular}{|c|c|c|c|c|c|c|c|c|c|}
\hline \multirow[t]{2}{*}{ Station } & \multirow[t]{2}{*}{ Latitude } & \multirow[t]{2}{*}{ Longitude } & \multirow[t]{2}{*}{$\mathrm{WD}(\mathrm{m})$} & \multirow{2}{*}{$\begin{array}{l}\mathrm{IP}_{25} \\
(\mu \mathrm{g} / \mathrm{g} \mathrm{OC})\end{array}$} & \multirow{2}{*}{$U_{37}^{K^{\prime}}$} & \multicolumn{2}{|c|}{ SST-alkenone temperature $\left({ }^{\circ} \mathrm{C}\right)$} & \multicolumn{2}{|l|}{ Residuals $\left({ }^{\circ} \mathrm{C}\right)$} \\
\hline & & & & & & $\begin{array}{l}\text { Müller } \\
\text { et al. (1998) }\end{array}$ & $\begin{array}{l}\text { Sikes } \\
\text { et al. (1997) }\end{array}$ & $\begin{array}{l}\text { Estimated SST } \\
\text { - WOA01 ma SST } \\
\text { (Müller et al., 1998) }\end{array}$ & $\begin{array}{l}\text { Estimated SST } \\
\text { - WOA01 summer SST } \\
\text { (Sikes et al., 1997) }\end{array}$ \\
\hline \multicolumn{10}{|c|}{ Western North Pacific } \\
\hline SO202-01-3 & 44.03 & 152.92 & 5282 & 0.000 & 0.427 & 11.6 & 13.4 & 5.1 & 1.5 \\
\hline SO202-02-4 & 46.97 & 156.98 & 4822 & 0.000 & 0.333 & 8.8 & 10.9 & 3.4 & 0.4 \\
\hline SO202-03-4 & 49.61 & 160.38 & 5429 & 0.000 & 0.386 & 10.4 & 12.3 & 5.2 & 2.2 \\
\hline SO202-04-3 & 51.86 & 163.16 & 5273 & 0.000 & 0.372 & 9.9 & 12.0 & 4.6 & 2.1 \\
\hline SO202-05-3 & 52.70 & 164.92 & 3362 & 0.000 & 0.277 & 7.1 & 9.4 & 1.7 & -0.3 \\
\hline SO202-06-2 & 51.90 & 166.49 & 3422 & 0.000 & 0.358 & 9.5 & 11.6 & 4.0 & 2.1 \\
\hline SO202-07-2 & 51.27 & 167.70 & 2349 & 0.000 & 0.317 & 8.3 & 10.5 & 2.8 & 1.2 \\
\hline SO202-08-1 & 50.54 & 170.82 & 3630 & 0.000 & 0.334 & 8.8 & 11.0 & 3.2 & 1.7 \\
\hline SO202-09-2 & 49.66 & 175.16 & 5028 & 0.000 & 0.407 & 11.0 & 12.9 & 5.0 & 3.4 \\
\hline \multicolumn{10}{|l|}{ Bering Sea } \\
\hline SO202-10-2 & 52.74 & 179.85 & 1488 & 0.000 & 0.310 & 8.1 & 10.3 & 2.8 & 2.0 \\
\hline SO202-11-1 & 53.11 & 178.90 & 2704 & 0.000 & 0.318 & 8.3 & 10.5 & 2.9 & 2.0 \\
\hline SO202-12-2 & 54.05 & 179.09 & 2108 & 0.000 & 0.284 & 7.3 & 9.6 & 1.9 & 1.1 \\
\hline SO202-13-4 & 54.98 & 177.96 & 1383 & 0.000 & 0.313 & 8.2 & 10.4 & 2.8 & 1.7 \\
\hline SO202-14-5 & 56.79 & 178.82 & 3822 & 0.000 & 0.266 & 6.7 & 9.2 & 1.9 & 0.4 \\
\hline SO202-15-4 & 59.51 & -179.85 & 3137 & 0.197 & 0.243 & 6.0 & 8.6 & 1.5 & 0.0 \\
\hline SO202-16-1 & 60.40 & -179.11 & 548 & 0.079 & 0.213 & 5.1 & 7.8 & 0.9 & -0.7 \\
\hline SO202-18-1 & 60.13 & -179.44 & 1108 & 0.567 & 0.256 & 6.4 & 8.9 & 2.3 & 0.4 \\
\hline SO202-19-1 & 57.65 & -175.68 & 1751 & 0.000 & 0.225 & 5.5 & 8.1 & 0.4 & -0.7 \\
\hline SO202-21-2 & 54.79 & -170.33 & 1911 & 0.000 & 0.257 & 6.5 & 8.9 & 1.4 & 0.4 \\
\hline SO202-22-1 & 54.57 & -168.81 & 1478 & 0.000 & 0.285 & 7.3 & 9.7 & 1.7 & 1.2 \\
\hline \multicolumn{10}{|c|}{ Eastern North Pacific } \\
\hline SO202-23-4 & 52.17 & -160.50 & 4613 & 0.000 & 0.325 & 8.5 & 10.7 & 1.7 & 0.0 \\
\hline SO202-24-2 & 53.00 & -157.19 & 4565 & 0.000 & 0.320 & 8.4 & 10.6 & 1.5 & -0.3 \\
\hline SO202-25-1 & 54.10 & -152.69 & 4588 & 0.000 & 0.368 & 9.8 & 11.8 & 2.8 & 0.5 \\
\hline SO202-26-1 & 54.64 & -150.38 & 742 & 0.000 & 0.379 & 10.2 & 12.1 & 3.1 & 0.7 \\
\hline SO202-27-1 & 54.30 & -149.60 & 2916 & 0.000 & 0.400 & 10.8 & 12.7 & 3.7 & 1.2 \\
\hline SO202-28-1 & 54.42 & -148.88 & 3710 & 0.000 & 0.372 & 9.9 & 11.9 & 2.8 & 0.4 \\
\hline SO202-29-5 & 52.03 & -148.89 & 3984 & 0.000 & 0.320 & 8.4 & 10.6 & 0.8 & -1.0 \\
\hline SO202-31-5 & 49.68 & -152.55 & 3744 & 0.000 & 0.345 & 9.1 & 11.3 & 1.3 & -0.3 \\
\hline SO202-32-5 & 45.50 & -158.50 & 5302 & 0.000 & 0.369 & 9.9 & 11.9 & 0.2 & -1.6 \\
\hline SO202-33-5 & 45.08 & -174.14 & 6159 & 0.000 & 0.383 & 10.3 & 12.2 & 1.8 & 0.0 \\
\hline \multicolumn{10}{|c|}{ Central North Pacific } \\
\hline SO202-34-2 & 40.89 & -177.68 & 5713 & 0.000 & 0.507 & 14.0 & 15.5 & 1.0 & -2.7 \\
\hline SO202-36-6 & 38.19 & 176.70 & 4522 & 0.000 & 0.565 & 15.8 & 17.0 & -0.2 & -3.6 \\
\hline SO202-37-1 & 37.77 & 176.27 & 3573 & 0.000 & 0.584 & 16.4 & 17.5 & -0.3 & -4.1 \\
\hline SO202-38-1 & 38.04 & 169.28 & 5503 & 0.000 & 0.573 & 16.0 & 17.2 & -0.4 & -3.2 \\
\hline SO202-39-2 & 38.01 & 164.45 & 5096 & 0.000 & 0.617 & 17.4 & 18.4 & 1.1 & -2.1 \\
\hline SO202-40-2 & 38.00 & 162.68 & 3462 & 0.000 & 0.566 & 15.8 & 17.1 & -0.6 & -3.7 \\
\hline SO202-41-3 & 38.41 & 160.33 & 5408 & 0.000 & 0.643 & 18.2 & 19.1 & 1.8 & -1.7 \\
\hline SO202-42-3 & 38.89 & 157.63 & 5535 & 0.000 & 0.641 & 18.1 & 19.0 & 2.6 & -1.8 \\
\hline SO202-45-2 & 40.29 & 149.49 & 5476 & 0.000 & 0.547 & 15.2 & 16.6 & 1.4 & -2.7 \\
\hline
\end{tabular}

\subsection{SST}

Alkenone-based $U_{37}^{K^{\prime}}$ SST values were determined for all surface sediment samples. $U_{37}^{K^{7}}$ was converted to SST according to the Müller et al. (1998) calibration $\left(U_{37}^{K^{\prime}}=0.033 T+0.044\right)$. This calibration was established using $U_{37}^{K^{\prime}}$ data from core-top sediments between $60^{\circ} \mathrm{S}$ and $60^{\circ} \mathrm{N}$ in the Atlantic, Indian and Pacific oceans and is applicable to a temperature range from 0 to $29^{\circ} \mathrm{C}$, with an error of ca. $\pm 1.4{ }^{\circ} \mathrm{C}$ (Herbert, 2003). The $U_{37}^{K^{\prime}}$-based SST values vary between 5.1 and $18.5^{\circ} \mathrm{C}$ (Table 2) and decrease northwards, following an expected latitudinal trend (Fig. 4a). Based on the correlation between $U_{37}^{K^{\prime}}$ in surface sediments and mean annual SST values extracted from World Ocean Atlas 2001 (WOA01), four regions were distinguished (Fig. 4). For the central North Pacific, the WOA01 mean annual SST shows the best agreement with the $U_{37}^{K^{\prime}}$-based SST, whereas the rest of the data set significantly diverges from the mean annual SST (Fig. 4b). In order to emphasise this observation, residuals have been calculated (Table 2; Fig. 4c) by subtracting the WOA01 SST from the respective $U_{37}^{K^{\prime}}$-based SST. The mean residual for all data points is about $+2{ }^{\circ} \mathrm{C}$, indicating an overestimation of the mean annual SST by the Müller et al. (1998) calibration. The residuals show, however, significant differences for the different regions. In the central North Pacific characterised by SST $>12^{\circ} \mathrm{C}$, the residuals display relatively low values, with an average deviation of $+0.7^{\circ} \mathrm{C}$ (Table 2, Fig. 4c). For the other three areas characterised by lower SST of $4-9{ }^{\circ} \mathrm{C}$, the residuals show that the $U_{37}^{K^{\prime}}$-based SST significantly overestimates the WOA01 mean annual SST, with an average deviation of $+3.9^{\circ} \mathrm{C}$ in the Western North Pacific, $+1.9{ }^{\circ} \mathrm{C}$ in the Bering Sea, and $+2{ }^{\circ} \mathrm{C}$ in the eastern North Pacific (Table 2, Fig. 4c).

The observations indicate that the calibration from Müller et al. (1998) offers acceptable SST estimates for the central North Pacific but may not be suitable for the colder water areas as it overestimates the mean annual SST. As suggested by Herbert (2003), the 

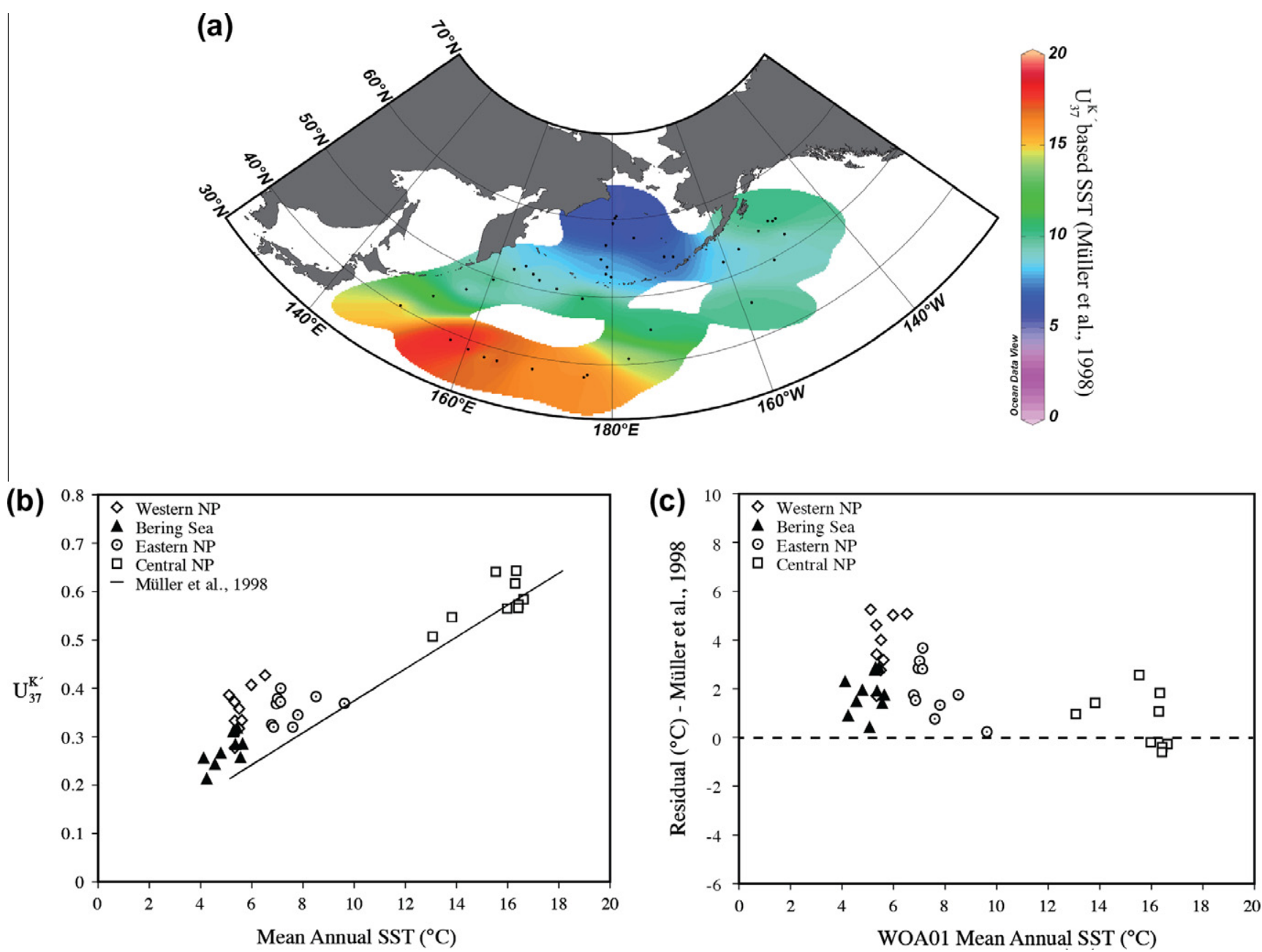

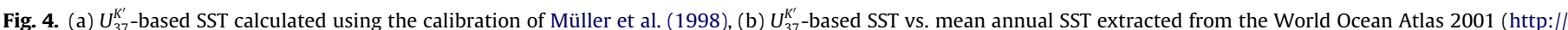

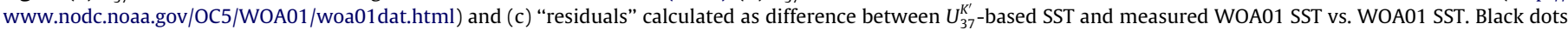
in (a) denote sites of sediment samples.

$U_{37}^{K^{\prime}}$ deviation should not be quantitatively interpreted for values $<0.2$ and $>0.96$ which, in terms of temperature, corresponds to $5{ }^{\circ} \mathrm{C}$ and $27^{\circ} \mathrm{C}$, respectively (according to Müller et al. (1998)).

Therefore, we also used the Sikes et al. (1997) calibration developed for cold water regions. This means that $U_{37}^{K^{\prime}}$ was converted to SST using their calibration $\left(U_{37}^{K^{\prime}}=0.038 T-0.082\right)$, which was obtained from core top sediments underlying Southern Ocean waters with summer temperature $>4{ }^{\circ} \mathrm{C}$. Using this equation, the $U_{37^{\prime}}^{K^{\prime}}$ based SST values range from 8.5 to $21.6^{\circ} \mathrm{C}$, with a decreasing latitudinal trend towards the north (Fig. 5a; Table 2).

Using the Sikes et al. (1997) calibration, the Western and Eastern North Pacific, as well as the Bering Sea data, seem to correlate quite well with the WOA01 summer SST (Fig. 5b). Model residuals provide further evidence, with a standard deviation of the $U_{37^{\prime}}^{K^{\prime}}$ based SST relative to WOA01 summer SST averaging $0.71{ }^{\circ} \mathrm{C}$ in the Bering Sea and $0{ }^{\circ} \mathrm{C}$ in the Eastern North Pacific (Table 2, Fig. 5c). However, the deviation is $+1.58{ }^{\circ} \mathrm{C}$ in the Western North Pacific, suggesting that the Sikes et al. (1997) calibration overestimates the summer SST, whereas in the central North Pacific this calibration underestimates the SST, as shown by the very negative residuals averaging $-2.8^{\circ} \mathrm{C}$ (Table 2 ; Fig. $5 \mathrm{c}$ ).

According to Sikes et al. (2005), the alkenone-based SST reproduces the SST values when alkenone flux is high, i.e., during the bloom of haptophyte algae. Our results assume that the alkenones were probably synthesised during different periods in different areas. In the Bering Sea, the alkenone producers seem to grow during a limited period, probably summer, when the most favourable conditions occur for a E. huxleyi bloom (i.e. strong stratification of the water column as a result of surface warming, low salinity and high light conditions; Iida et al., 2012). In the eastern Bering Sea, $E$. huxleyi blooms show interannual and seasonal variability (Iida et al., 2012), but within the last few decades, massive blooms have occurred in June and/or September. Little is known about blooms in the western North Pacific, but all the favourable bloom conditions are observed in summer in the area (Stabeno et al., 2004) and control the phytoplankton community bloom, including most probably the E. huxleyi bloom (Prahl et al., 2010). In the central North Pacific, the phytoplankton bloom, including coccolithophores, was probably spread over a longer period, which would explain why the Müller et al. (1998) calibration offers a better estimate of mean annual SST in the area.

In general, our results are in line with several studies of alkenone-based SST reconstructions. Sikes et al. (1997) showed that the $U_{37}^{K^{\prime}}$-based SST for the water column and surface sediments from the Southern Ocean reflects the SST of times characterised by maximum productivity and thus the flux of biomarkers to the sediment, i.e. during spring-summer accompanied by the phytoplankton blooms. Harada et al. (2003) published similar conclusions for the eastern Bering Sea. The calculated SST from the surface sediments corresponds to the September SST, and this 

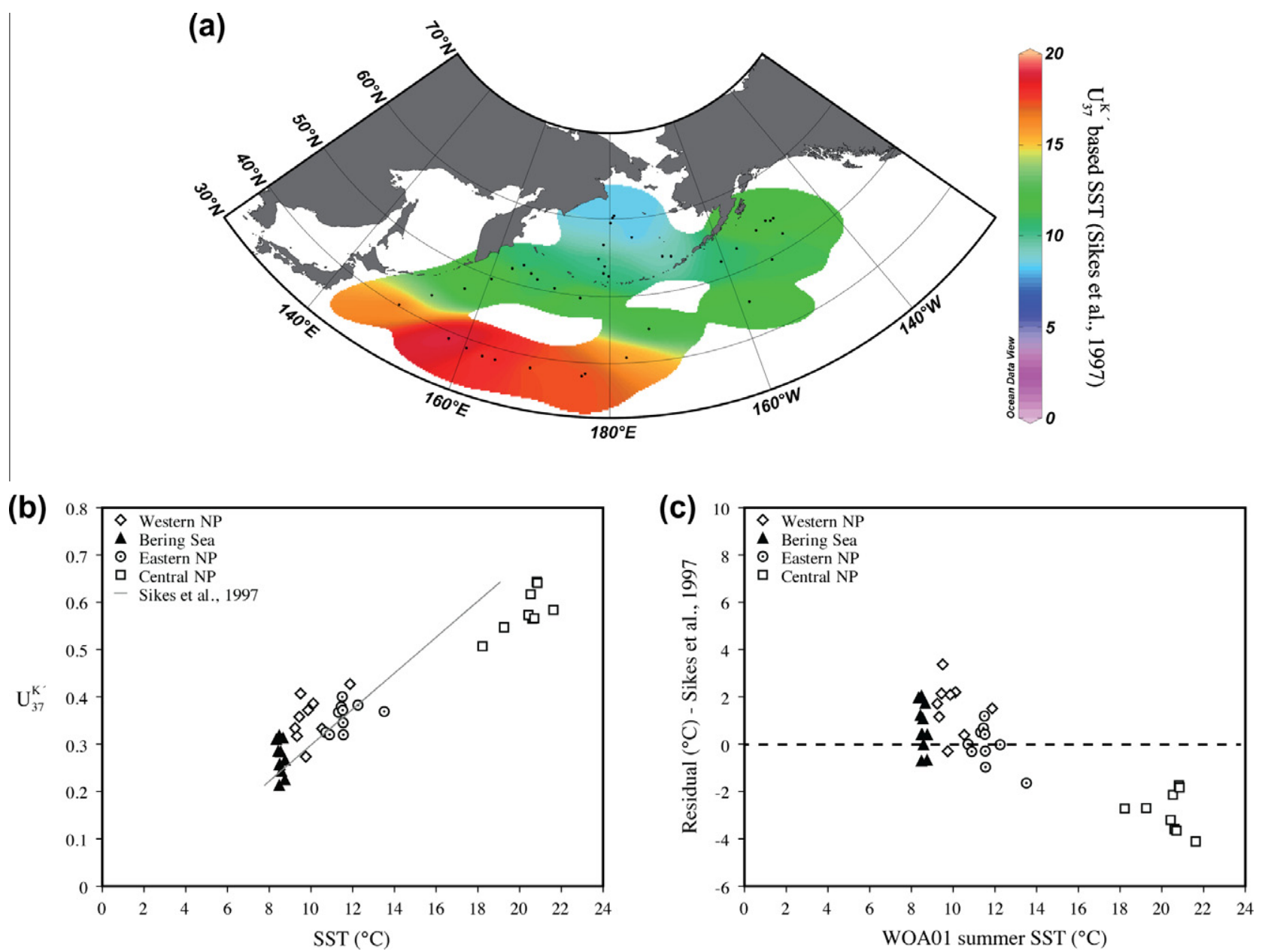

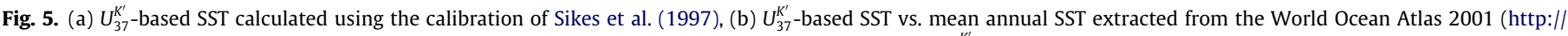

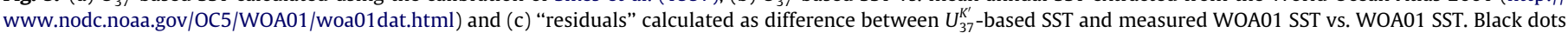
in (a) denote sites of sediment samples.

period was proposed to be the most productive time interval for the alkenone-synthesising organisms in the area. Finally, the results are supported by the studies by Prahl et al. (2010) to explain warmer estimated SST vs. measured mean annual SST for surface sediments from southeast Alaska, the North Atlantic and along the Southern Chilean margin.

\subsection{Sea ice distribution}

The distribution of the sea ice biomarker $\mathrm{IP}_{25}$ in the Bering Sea and the North Pacific (Fig. 6b) is compared with the maximum (March) sea ice distribution pattern in Fig. 6a. Low $\mathrm{IP}_{25}$ concentration $(0.08-0.57 \mu \mathrm{g} / \mathrm{g}$ TOC) was found in three sediment samples from the northern Bering Sea, northwards of the $20 \%$ sea ice extension in March (Fig. 6a). The occurrence of $\mathrm{IP}_{25}$ in these samples is indicative of the presence of sea ice at the Bering Sea shelf break. The accompanying growth of phytoplankton is reflected in the relatively high concentration of phytoplankton-derived brassicasterol and dinosterol $(12-281 \mu \mathrm{g} / \mathrm{g}$ TOC and 5-109 $\mu \mathrm{g} / \mathrm{g}$ TOC, respectively) in these samples. The co-occurrence of $\mathrm{IP}_{25}$ and phytoplankton-derived biomarkers suggest a seasonal (spring) sea ice cover at the Bering Sea shelf break (cf. Müller et al., 2009, 2011).

$\mathrm{IP}_{25}$ was absent from all the other samples from the Bering Sea and North Pacific, whereas the phytoplankton-produced biomarkers, brassicasterol and dinosterol, were present in most of them (7-281 $\mu \mathrm{g} / \mathrm{g}$ TOC and 1.7-109 $\mathrm{g} / \mathrm{g}$ TOC, respectively). The good correlation between brassicasterol and dinosterol (correlation coefficient of $r^{2}$ 0.69) and absence of $\mathrm{IP}_{25}$ underline an open water phytoplankton origin for both sterols in these areas (cf. Müller et al., 2011; Fahl and Stein, 2012; Stein et al., 2012). Brown et al. (2011) also determined only a very minor concentration of brassicasterol in sea ice samples from the Canadian Beaufort Sea $(<3 \%$ of total sterols). This is in contrast to Yunker et al. (1995) who found a significant concentration of brassicasterol in sediment trap samples from the Beaufort Sea at spring times when there was still a100\% ice cover, and thus interpreted brassicasterol as being produced by ice algae. Our results are consistent with the maximum and minimum sea ice extent in the Bering Sea as highlighted in Figs. 1 and 6 (Danielson et al., 2011). Furthermore, the results indicate that $\mathrm{IP}_{25}$ seems to be a reliable sea ice proxy in the Bering Sea and the North Pacific, reinforcing its use in future palaeo-sea ice reconstructions in these areas.

\section{Conclusions}

On the Bering slope, the "Green Belt" area, the OM is mainly of marine origin, as shown by the good correlation between high $\mathrm{HI}$ values and the maximum dinosterol and brassicasterol concentration in the area. In the North Pacific, low HI values and high concentration of long chain $n$-alkanes indicate a predominantly higher plant origin for the OM. This terrigenous input is probably caused by dust supply from the Asian continent to the North Pacific via westerly winds and ocean currents. 

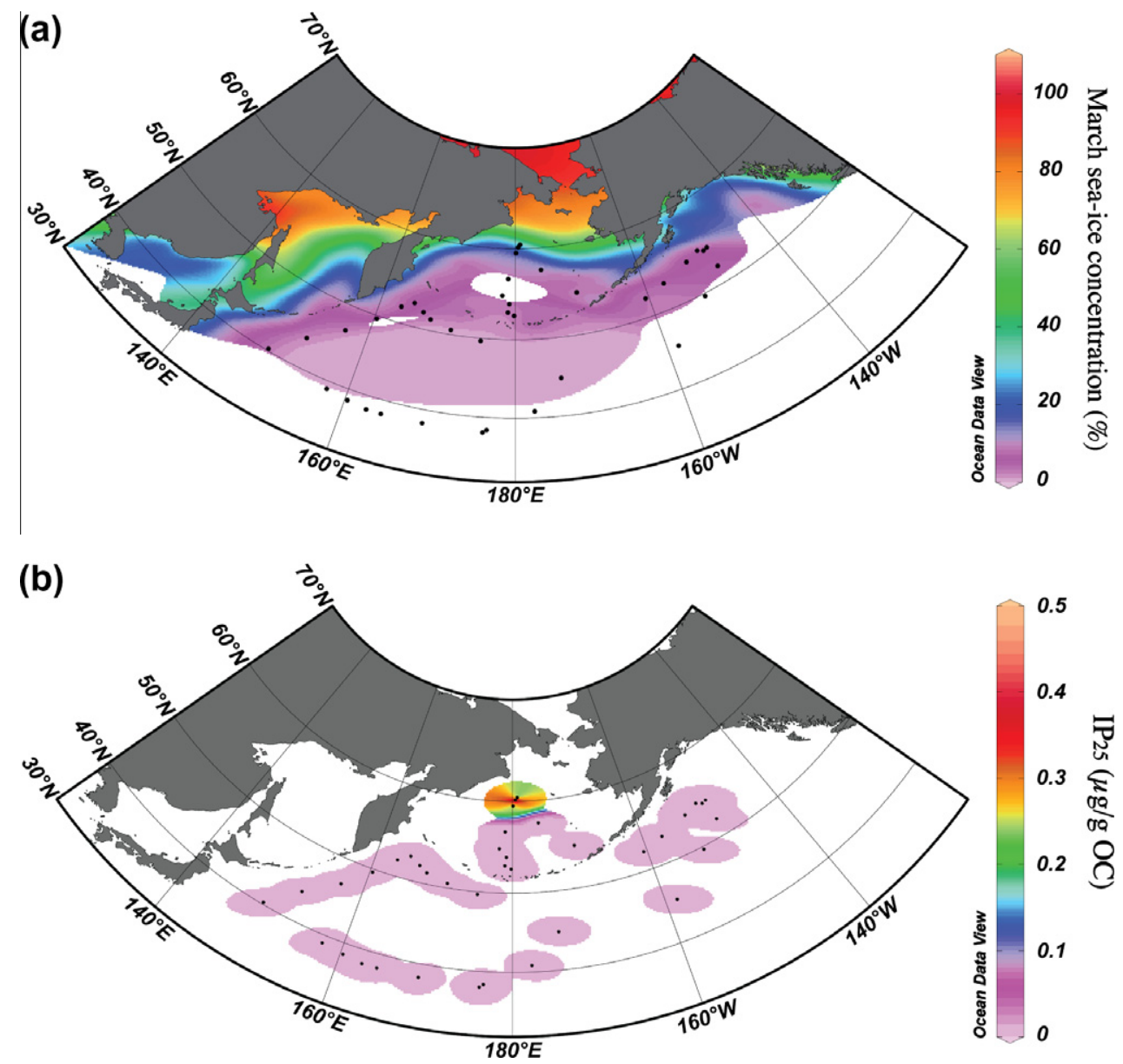

Fig. 6. (a) Map of March sea ice extent (\%) based on data from the National Snow and Ice Data Center (NSIDC), averaged over the period from 1978 to 2007 (http://nsidc.org/) and (b) concentration of $\mathrm{IP}_{25}(\mu \mathrm{g} / \mathrm{g} \mathrm{OC})$ in surface sediments from the North Pacific and Bering Sea. Black dots indicate sites where sediments were collected.

The alkenone unsaturation index $\left(U_{37}^{K^{\prime}}\right)$ was converted to SST using two different calibrations (Müller et al., 1998 and Sikes et al., 1997). The Müller et al. (1998) calibration probably offers a more accurate estimate of mean annual SST in the central North Pacific, whereas the Sikes et al. (1997) calibration seems to be more accurate for the eastern North Pacific and the Bering Sea, characterised by colder SST $<9{ }^{\circ} \mathrm{C}$, and provides reasonable summer SST estimates. However, it overestimates summer SST in the western North Pacific.

The sea ice proxy, $\mathrm{IP}_{25}$, was only found in samples from north of the March ice edge. Its absence from the rest of the investigated area is, on the other hand, in agreement with the open water conditions observed in the North Pacific and the southern part of the Bering Sea.

\section{Acknowledgments}

This study is a contribution to the international INOPEX (Innovative North Pacific Experiment) Project funded by the German Ministry of Education and Science (Bundesministerium für Bildung und Forschung) and the German Research Foundation (DFG), project STE412/25. Thanks go to the chief scientist of the INOPEX cruise, R. Gersonde. We thank the captain of the research vessel $\mathrm{R} / \mathrm{V}$ Sonne, L. Mallon, as well as the crew members and the scientists on board for their remarkable work and the great atmosphere during the expedition. We are also grateful to W. Luttmer and S. Wassmuth for technical support in the laboratory. We also appre- ciate the comments and suggestions from M.B. Yunker and an anonymous reviewer.

\section{Associate Editor-J.K. Volkman}

\section{References}

Amo, M., Minagawa, M., 2003. Sedimentary record of marine and terrigenous organic matter delivery to the Shatsky Rise, western North Pacific, over the last 130 kyr. Organic Geochemistry 34, 1299-1312.

Andrews, J.T., Belt, S.T., Olafsdottir, S., Massé, G., Vare, L.L., 2009. Sea ice and marine climate variability for NW Iceland/Denmark Strait over the last 2000 cal. yr BP Holocene 19, 775-784.

Bao, K., Xing, W., Yu, X., Zhao, H., McLaughlin, N., Lu, X., Wang, G., 2012. Recent atmospheric dust deposition in an ombrotrophic peat bog in Great Hinggan Mountain, Northeast China. Science of the Total Environment 431, 33-45.

Belt, S.T., Massé, G., Rowland, S.J., Poulin, M., Michel, C., LeBlanc, B., 2007. A novel chemical fossil of palaeo sea ice: $\mathrm{IP}_{25}$. Organic Geochemistry 38, 16-27.

Belt, S.T., Vare, L.L., Massé, G., Manners, H., Price, J., MacLachlan, S., Andrews, J.T. Schmidt, S., 2010. Striking similarities in temporal changes to spring sea ice occurrence across the central Canadian Arctic Archipelago over the last 7000 years. Quaternary Science Reviews 29, 3489-3504.

Birgel, D., Stein, R., Hefter, J., 2004. Aliphatic lipids in recent sediments of the Fram Strait/Yermak Plateau (Arctic Ocean): composition, sources and transport processes. Marine Chemistry 88, 127-160.

Boetius, A., Damm, E., 1998. Benthic oxygen uptake, hydrolytic potentials and microbial biomass at the Arctic continental slope. Deep-Sea Research I 45, 239275.

Bonnet, S., de Vernal, A., Gersonde, R., Lembke-Jene, L., 2012. Modern distribution of dinocysts from the North Pacific Ocean $\left(37-64^{\circ} \mathrm{N}, 144^{\circ} \mathrm{E}-148^{\circ} \mathrm{W}\right)$ in relation to hydrographic conditions, sea-ice and productivity. Marine Micropaleontology 84-85, 87-113. 
Boon, J.J., Rijpstra, W.I.C., de Lange, F., de Leeuw, J.W., Yoshioka, M., Shimizu, Y., 1979. The Black Sea sterol - a molecular fossil for dinoflagellate blooms. Nature 277, 125-127.

Brassell, S.C., Eglinton, G., Marlowe, I.T., Pflaumann, U., Sarnthein, M., 1986 Molecular stratigraphy: a new tool for climatic assessment. Nature 320, 129133.

Brown, T.A., Belt, S.T., Philippe, B., Mundy, C.J., Massé, G., Poulin, M., Gosselin, M. 2011. Temporal and vertical variations of lipid biomarkers during a bottom ice diatom bloom in the Canadian Beaufort Sea: further evidence for the use of the $\mathrm{IP}_{25}$ biomarker as a proxy for spring Arctic sea ice. Polar Biology 34, 1857-1868.

Danielson, S., Curchitser, E., Hedstrom, K., Weingartner, T., Stabeno, P., 2011. On ocean and sea ice modes of variability in the Bering Sea. Journal of Geophysical Research 116, C12034.

Eglinton, G., Hamilton, R.J., 1963. The distributions of alkanes. In: Swain, T. (Ed.) Chemical Plant Taxonomy. Academic Press, New York, pp. 187-217.

Eglinton, G., Hamilton, R.J., 1967. Leaf epicuticular waxes. Science 156, 1322-1335.

Espitalié, J., Laporte, J.L., Madec, M., Marquis, F., Leplat, P., Paulet, J., Boutefeu, A. 1977. Méthode rapide de caractérisation des roches mères, de leur potentiel pétrolier et de leur degré dévolution. Revue de IInstitut Franccais du Pétrole 32, 23-42.

Fahl, K., Stein, R., 1997. Modern organic carbon deposition in the Laptev Sea and the adjacent continental slope: surface-water productivity vs. terrigenous input Organic Geochemistry 26, 379-390.

Fahl, K., Stein, R., 1999. Biomarkers as organic-carbon-source and environmental indicators in the Late Quaternary Arctic Ocean: problems and perspectives. Marine Chemistry 63, 293-309.

Fahl, K., Stein, R., 2012. Modern seasonal variability and deglacial/Holocene change of central Arctic Ocean sea-ice cover: new insights from biomarker proxy records. Earth and Planetary Science Letters 351-352, 123-133.

Gersonde, R., 2012. The Expedition of the Research Vessel "Sonne" to the Subpolar North Pacific and the Bering Sea in 2009 (SO202-INOPEX). Report on Polar and Marine Research, Bremerhaven, 643, 323 p. ISSN: 1866-3192.

Harada, N., Shin, K.H., Murata, A., Uchida, M., Nakatani, T., 2003. Characteristics of alkenones synthesized by a bloom of Emiliania huxleyi in the Bering Sea. Geochimica et Cosmochimica Acta 67, 1507-1519.

Herbert, T.D., 2003. Alkenones as paleotemperature indicators. In: Holland, H.D., Turekian, K.K. (Eds.), Treatise on Geochemistry, vol. 6. Elsevier, pp. 391-432.

Huang, W.Y., Meinschein, W.G., 1976. Sterols as source indicators of organic materials in sediments. Geochimica et Cosmochimica Acta 40, 323-330.

Hunt, G.L., Stabeno, P.J., Walters, G., Sinclair, E., Brodeur, R.D., Napp, J.M., Bond, N.A., 2002. Climate change and control of the southeastern Bering Sea pelagic ecosystem. Deep-Sea Research II 49, 5821-5853.

Iida, T., Saitoh, S.-I., 2007. Temporal and spatial variability of chlorophyll concentrations in the Bering Sea using empirical orthogonal function (EOF) analysis of remote sensing data. Deep-Sea Research II 54, 2657-2671.

lida, T., Mizobata, K., Saitoh, S.-I., 2012. Interannual variability of coccolithophore Emiliania huxleyi blooms in response to changes in water column stability in the eastern Bering Sea. Continental Shelf Research 34, 7-17.

Katsuki, K., Takahashi, K., 2005. Diatoms as paleoenvironmental proxies for seasonal productivity, sea-ice and surface circulation in the Bering Sea during the late Quaternary. Deep-Sea Research II 52, 2110-2130.

Kawahata, H., Ohshima, H., 2002. Small latitudinal shift in the Kuroshio Extension (Central Pacific) during glacial time: evidence from pollen transport. Quaternary Science Reviews 21, 1705-1717.

Kawahata, H., Okamoto, T., Matsumoto, E., Ujiie, H., 2000. Fluctuations of eolian flux and ocean productivity in the mid-latitude North Pacific during the last $200 \mathrm{kyr}$. Quaternary Science Reviews 19, 1279-1291.

Marlowe, I.T., Brassell, S.C., Eglinton, G., Green, J.C., 1984. Long chain unsaturated ketones and esters in living algae and marine sediments. Organic Geochemistry $6,135-141$.

Massé, G., Rowland, S.J., Sicre, M., Jacob, J., Jansen, E., Belt, S.T., 2008. Abrupt climate changes for Iceland during the last millennium: evidence from high resolution sea ice reconstructions. Earth and Planetary Science Letters 269, $565-569$.

Mizobata, K., Saitoh, S., 2004. Variability of Bering Sea eddies and primary productivity along the shelf edge during 1998-2000 using satellite multisensor remote sensing. Journal of Marine Systems 50, 101-111.

Mizobata, K., Saitoh, S., Shiomoto, S., Miyamura, T., Shiga, N., Toratani, M., Kajiwara, Y., Sasaoka, K., 2002. Bering Sea cyclonic and anticyclonic eddies observed during summer 2000 and 2001. Progress in Oceanography 55, 65-75.

Müller, P.J., Kirst, G., Rhuland, G., von Storch, I., Rosell-Melé, A., 1998. Calibration of the alkenone paleotemperature index $U_{37}^{\mathrm{K}^{\prime}}$ based on core-tops from the eastern South Atlantic and the global ocean $\left(60^{\circ} \mathrm{N}-60^{\circ} \mathrm{S}\right)$. Geochimica et Cosmochimica Acta 62, 1757-1772.

Müller, J., Massé, G., Stein, R., Belt, S.T., 2009. Variability of sea-ice conditions in the Fram Strait over the past 30,000 years. Nature Geoscience 2, 772-776.

Müller, J., Wagner, A., Fahl, K., Stein, R., Prange, M., Lohmann, G., 2011. Towards quantitative sea ice reconstructions in the northern North Atlantic: a combined biomarker and numerical modelling approach. Earth and Planetary Science Letters 306, 137-148.

Müller, J., Werner, K., Stein, R., Fahl, K., Moros, M., Jansen, E., 2012. Holocene cooling culminates in sea ice oscillations in Fram Strait. Quaternary Science Reviews 47 $1-14$.

Nichols, P.D., Jones, G.J., de Leeuw, J.W., Johns, R.B., 1984. The fatty acid and sterol composition of two marine dinoflagellates. Phytochemistry 23, 1043-1047.
Niebauer, H.J., 1980. Sea ice and temperature variability in the eastern Bering Sea and the relation to atmospheric fluctuations. Journal of Geophysical Research $85,7507-7515$.

Niebauer, H.J., 1983. Multiyear sea ice variability in the eastern Bering Sea: an update. Journal of Geophysical Research 88, 2733-2742.

Niebauer, H.J., Alexander, V., Henrichs, S., 1990. Physical and biological oceanographic interaction in the spring bloom at the Bering Sea marginal ice edge zone. Journal of Geophysical Research 95, 22229-22241.

Niebauer, H.J., Alexander, V., Henrichs, S.M., 1995. A time-series study of the spring bloom at the Bering Sea marginal ice edge zone. I. Physical processes, chlorophyll and nutrient chemistry. Continental Shelf Research 15, 18591877.

Okkonen, S.R., Schmidt, G.M., Cokelet, E.D., Stabeno, P.J., 2004. Satellite and hydrographic observations of the Bering Sea 'Green Belt'. Deep-Sea Research II 51, 1033-1051.

Overland, J.E., 1981. Marine climatology of the Bering Sea. In: Hood, D.W., Calder J.A. (Eds.), The Eastern Bering Sea shelf: Oceanography and Resources, vol. 1. NOAA, University of Washington Press, Seattle, pp. 15-22.

Prahl, F.G., Wakeham, S.G., 1987. Calibration of unsaturation patterns in long-chain ketone compositions for palaeotemperature assessment. Nature 330, 367-369.

Prahl, F.G., Muehlhausen, L.A., Zahnle, D.L., 1988. Further evaluation of long-chain alkenones as indicators of paleoceanographic conditions. Geochimica et Cosmochimica Acta 52, 2303-2310.

Prahl, F.G., Rontani, J.-F., Zabeti, N., Walinsky, S.E., Sparrow, M.A., 2010. Systematic pattern in $U_{37}^{K^{\prime}}$-temperature residuals for surface sediments from high latitude and other oceanographic settings. Geochimica et Cosmochimica Acta 74, 131143.

Prospero, J.M., Uematsu, M., Savoie, D.L., 1989. Mineral aerosol transport to the Pacific Ocean. In: Chemical Oceanography, vol. 10, pp. 187-218.

Qiu, B., 2000. Interannual variability of the Kuroshio Extension system and its impact on the wintertime SST field. Journal of Physical Oceanography 30, 14861502.

Schubert, C.J., Stein, R., 1997. Lipid distribution in surface sediments from the eastern central Arctic Ocean. Marine Geology 138, 11-25.

Schumacher, J.D., Reed, R.K., 1992. Characteristics of currents over the continental slope of the eastern Bering Sea. Journal of Geophysical Research 97, 9423-9433.

Sicre, M.-A., Ternois, Y., Paterne, M., Boireau, A., Beaufort, L., Martinez, P., Bertrand P., 2000. Biomarker stratigraphic records over the last 150 kyears off the NW African coast at $25^{\circ} \mathrm{N}$. Organic Geochemistry 31, 577-588.

Sikes, E.L., Volkman, J.K., Robertson, L.G., Pichon, J.-J., 1997. Alkenones and alkenes in surface waters and sediments of the Southern Ocean: implications for paleotemperature estimation in polar regions. Geochimica et Cosmochimica Acta 61, 1495-1505.

Sikes, E.L., ÓLeary, T., Nodder, S.D., Volkman, J.K., 2005. Alkenone temperature records and biomarker flux at the subtropical front on the Chatham Rise, SW Pacific Ocean. Deep-Sea Research 52, 721-748.

Springer, A.M., McRoy, C.P., Flint, M.V., 1996. The Bering Sea Green Belt: shelf-edge processes and ecosystem production. Fisheries Oceanography 5, 205-223.

Stabeno, P.J., Reed, R.K., 1994. Circulation in the Bering Sea basin by satellite tracked drifters. Journal of Physical Oceanography 24, 848-854.

Stabeno, P.J., Bond, N.A., Hermann, A.J., Kachel, N.B., Mordy, C.W., Overland, J.E., 2004. Meteorology and oceanography of the Northern Gulf of Alaska. Continental Shelf Research 24, 859-897.

Stabeno, P.J., Bond, N.A., Salo, S.A., 2007. On the recent warming of the southeastern Bering Sea shelf. Deep-Sea Research 54, 2599-2618.

Stabeno, P.J., Napp, J., Mordy, C.W., Whitledge, T., 2010. Factors influencing physical structure and lower trophic levels of the eastern Bering Sea shelf in 2005: sea ice, tides and winds. Progress in Oceanography 85, 180-196.

Stein, R., 2008. Arctic Ocean sediments: Processes, Proxies, and Paleoenvironment. Developments in Marine Geology, 2. Elsevier, Amsterdam, 592 pp.

Stein, R., Macdonald, R.W. (Eds.), 2004. The Organic Carbon Cycle in the Arctic Ocean. Springer Verlag, Heidelberg, 363 pp.

Stein, R., Fahl, K., 2012. A first southern Lomonosov Ridge (Arctic Ocean) $60 \mathrm{ka} \mathrm{IP}_{25}$ sea-ice record. Polarforschung $82,83-86$.

Stein, R., Fahl, K., Müller, J., 2012. Proxy reconstruction of Arctic Ocean sea ice history: From IRD to $\mathrm{IP}_{25}$. Polarforschung $82,37-71$.

Tissot, B.P., Welte, D.H., 1984. Petroleum Formation and Occurrence. Springer Verlag, Heidelberg, 699 pp.

Tsyban, A.V., 1999. The BERPAC Project: development and overview of ecological investigations in the Bering and Chukchi Seas. In: Loughlin, T.R., Ohtani, K. (Eds.), Dynamics of the Bering Sea. University of Alaska Sea Grant, Fairbanks, pp. 713-731.

Uematsu, M., Duce, R.A., Prospero, J.M., Chen, L., Merrill, J.T., McDonald, R.L., 1983. Transport of mineral aerosol from Asia over the North Pacific Ocean. Journal of Geophysical Research 88, 5343-5352.

Vare, L.L., Massé, G., Gregory, T.R., Smart, C.W., Belt, S.T., 2009. Sea ice variations in the central Canadian Arctic Archipelago during the Holocene. Quaternary Science Reviews 28, 1354-1366.

Volkman, J.K., 1986. A review of sterol markers for marine and terrigenous organic matter. Organic Geochemistry 9, 83-89.

Volkman, J.K., 2006. Lipid markers for marine organic matter. In: Volkman, J.K. (Ed.), Handbook of Environmental Chemistry. Springer-Verlag, Berlin, Heidelberg, pp. 27-70.

Volkman, J.K., Eglinton, G., Corner, E.D.S., Forsberg, T.E.V., 1980. Long-chain alkenes and alkenones in the marine coccolithophorid Emiliania huxleyi. Phytochemistry 19, 2619-2622. 
Walinsky, S.E., Prahl, F.G., Mix, A.C., Finney, B.P., Jaeger, J.M., Rosen, G.P., 2009 Distribution and composition of organic matter in surface sediments of coastal Southeast Alaska. Continental Shelf Research 29, 1565-1579.

Yunker, M.B., Macdonald, R.W., Veltkamp, D.J., Cretney, W.J., 1995. Terrestrial and marine biomarkers in a seasonally ice-covered Arctic estuary-integration of multivariate and biomarker approaches. Marine Chemistry 49, 1-50.
Yunker, M.B., Belicka, L.L., Harvey, H.R., Macdonald, R.W., 2005. Tracing the inputs and fate of marine and terrigenous organic matter in Arctic Ocean sediments: a multivariate analysis of lipid biomarkers. Deep-Sea Research II 52, 3478-3508. 